PART THREE

EVERYDAY CULTURE 


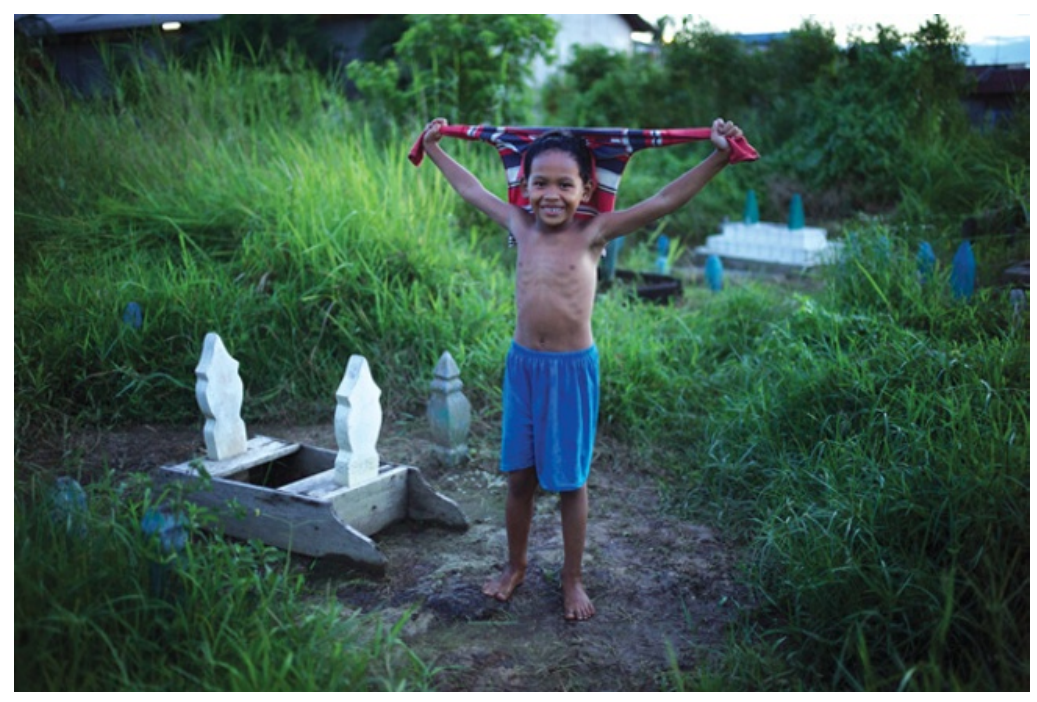

Fig 7. PONTIANAK: The city is built on top of a swamp, with houses on stilts or piles; sometimes when a big truck passes by, you can almost see the asphalt ripple like a wave under its tires (and you can definitely feel the hollow reverberations). In some neighbourhoods the only dry land is the cemetery, which therefore doubles as a playground.

May 2010: photo by S. Chris Brown 


\title{
GROWING UP IN KUPANG
}

\author{
Cornelis Lay (edited, translated and with an introduction \\ by Gerry van Klinken $)^{1}$
}

\begin{abstract}
Yogya
On 15 May 1979 I left Kupang for the famous student town of Yogyakarta, in the heart of Java. Flying on a Merpati Airlines Fokker 27, my friend George Eman and I - he was of Dutch descent and we always called him Ge or just Whitey (Bule) - transited in Denpasar and reached Surabaya in the afternoon. It was my first time in an aeroplane. All my childhood
\end{abstract}

\section{${ }^{1}$ Editorial introduction}

Connie Lay's memories of this quiet provincial town in the late 196os and the 1970 s are bathed in the radiant light of adolescence. As he and his mates roamed the deserted shopping street in the dark, he recalled, 'there was no other sound besides our chatter: Kupang at night was a peaceful village, our village.' Happiness was belonging; it was knowing what everyone was eating and even knowing their underwear. Given a chance to choose again, he would have it no different, he tells us at the end. The question for the reader is how reliable these memories are. Do they tell us something about Kupang in the 1970s, or do they merely reveal the mid-life nostalgia of a successful academic, who left this city behind almost 35 years ago, and, with it, his kampung origins? These memories are, after all, just that - there is no box with letters, diaries, photos, favourite books, clippings or homework assignments. The answer is probably a bit of both. The technique of 'interviewing the self' brought back a flood of detailed memories that had for decades lain dormant. Stories of freedom any well-adjusted boy retains - of racing after kites, of watching big boys fight, sneaking into the movies, and teasing the town idiot. But also stories that grow out of middle-age nostalgia, wishing to honour parents and friends, polite memories from which, for example, adolescent voluptuous fantasies have been purged. Kupang has been good to Connie Lay. We cannot help wondering whether the mates who were left behind in the market, functionally illiterate, shut out from the easy life of the 'boss boss' civil servants, and by now with numerous children to support, have memories as suffused with warmth as this.

Nevertheless, like Carolyn Steedman's (1987) autobiograpy of life in the British lower class, in which critics also saw middle class romanticization of an

(c) CORNELIS LAY, 2014.

This is an open access chapter distributed under the terms of the Creative Commons Attribution-Noncommercial-NonDerivative 3.o Unported (CC-BY-NC-ND 3.0) License. 
dreams of flying came rushing back during the long flight. An extraordinary sensation. We were met by a business partner of Ge's dad - after he retired from the police, Uncle Eman had become an agent for Comfeed chicked feed - and were put up in a small hotel in a part of Surabaya that

impoverished past, this one depicts something beyond an unusual personal success story. Lay's recollection of an urgent desire for upward mobility was not unique to him. His mother felt the same urge and worked hard to satisfy it through her son. Many lower-class kampung dwellers in provincial towns today continue to share the dream, as we can read in Wenty Marina Minza's and Jan Newberry's contributions to this volume. In that respect Kupang of the 1970s differed from Clifford Geertz's stagnating Mojokuto of the 1950s, which was 'stranded, at least for the moment, between the heritage of yesterday and the possibilities of tomorrow' (1963b:17). The poor in Kupang had no cultural reservations about tomorrow. They just had the devil of a job to get there.

Lay is as fascinated with class difference as with the possibilities of bridging it. In this respect, too, his account confirms those of Minza and Newberry. Yes, he denies the class differences were sharp. In his memory the town was as united, peaceful, plural and accepting as any town could be. The boys' games seemed to be a cross-class celebration of solidarity among kids against adults, reinforced by an esoteric youth language. Yet the differences remained real, and I would not be surprised if they were sharper than Lay's warm feelings towards his home town now allow him to admit. The poor deployed a clear terminology for the rich. They called them 'big people', 'big boss', 'boss boss', or, as the ultimate condemnation for exclusive behaviour, 'rich people'. Granted, the lack of neighbourly solidarity the well-off showed towards others might, at least on the surface, also be seen as their own form of poverty. And not everything about the peculiar obsessions the 'big people' seemed to hold dear was necessarily attractive. Their concern for hygiene seemed excessive, as did their fixation with the orderly practices of prayer and church attendance. Yet, a lower-class boy who sat at school with them still felt inferior in their presence. Their parents had an ease of access to the state and the church that his own parents did not, much as they tried to contort their speech into formal Indonesian. Other contributions in this volume (notably by Nico Warouw and Sylvia Tidey) confirm that this access defined the boundary between the indigenous middle and lower classes.

Kupang at this time had around 50,000 inhabitants and was growing rapidly. It had been the capital of the large province of East Nusa Tenggara since 1959. The oil-fueled New Order regime began transforming provincial townscapes all over the archipelago in the 1970s. Leirissa, Kuntowidjojo and Soenjata Kartadarmadja's (1984) post-war social history of Kupang, and I.H. Doko's (1982) description of a drive around the town in the same period makes delightful reading, but neither so convincingly portrays life 'from below' as Cornelis Lay does here. Connie's father 
happened to be called Kupang also. The next evening we took the night bus to Yogya and arrived before dawn. Using a cycle rickshaw (becak) another first, since the only one I knew in Kupang was used by a Sabu man to carry foodstuffs at the Pelita market - we headed for the home of a relative who taught at Gadjah Mada University. I called him Uncle Josef.

was a papalele, an itinerant trader. The draft book from which this chapter was extracted relates the constant moving that this life involved. Arriving from Sabu in the late 1940s, he first laboured in the harbour, then rode trucks into the interior to buy cattle skins, tamarind and candlenut, and finally ran a succession of stalls with the whole family in the heart of Kupang. As a local government full of development plans repeatedly evicted them, the stall crept gradually down the street and from one marketplace to another. Now father was selling rice, now meat off-cuts (jeroan). Young Connie, meanwhile, roved the town selling cakes and packets of cooked rice, finding pretty stones to sell, gambling with his friends at a funeral, or looking for scrap timber to repair the house. Or else he spent boring afternoons looking after mum and dad's stall.

Bonds of patronage sometimes reached across the class divide. Connie Lay's own story starts when his mother engages in a spectacularly brave claim on such patronage on behalf of her son. She confronts both the local head of education and the provincial deputy governor and announces she is their 'sister', though she hasn't seen either of them more than once in two decades. It works like a charm. They embrace her and write the necessary letters. And of course Connie Lay has the native talent to repay their faith. But there is a less tractable side to the class difference as well. During the anti-communist purges beginning in late 1965 soldiers carried off several inhabitants of the poor Dendeng neighbourhood where they lived; they were never seen again. We do not learn here how many people in the kampung had been interested in politics, but these events put an end to all that. Violence was said to be rare, yet when it did erupt, it was often related to the military. Kupang was the mobilizational base for the invasion of East Timor in late 1975. Once back in town, East Timor veterans acted out their violent feuds with the police on the streets. Young military men who lost their 'duels' would call on their mates to trash the house of a non-military winner.

Put together, we have a tantalizing glimpse from below of provincial-town life in a developing country at a moment of rapid change. The sense of being connected to 'events and places in various ways' touched every corner of this apparently quiet town. The subtle tension in the story arises when one of the 'people with woes' (orang susah) sets out on a quest to get even closer to the action, and discovers that small-town intimacy by no means implies equality.

Gerry van Klinken

Our thanks to Amalinda Savirani for suggesting the outline of this chapter, and to Chris Brown for suggesting the Steedman reference. 
His full name was Josef Riwu Kaho, he was related to my mother. The family came from Sabu, a little island between Timor and Sumba, but he had been born and raised in Atambua, a small town that I only visited once, before the 1977 election, $240 \mathrm{~km}$ from Kupang. Uncle Josef's nuclear family probably had ten members, but there were about 60 others sleeping in a long barracks there, too. As was the custom, migrants from the kampung were put up with family already there. He had come to Yogya in 1959, finished his studies and stayed on as a lecturer. Thousands of his students remember him, mainly for his tough discipline. We called him a 'killer', with 'Dutch discipline'. When Uncle Josef was in junior high, in the early 1950s, he lived right next door to us, in a house owned by the labour boss Simon Boeboe, who was affiliated with the communist party. It is said that Uncle Simon was killed in the big purge of 'communists.' The land we lived on was a gift from him.

When we got to his house it was still very early, about 6 a.m., but he was up. The house, which he still occupies, lay in the Baciro area and was a Home Affairs Department residence for lecturers at Gadjah Mada University (UGM) training mid-level bureaucrats for all of Indonesia. The house looked friendly and there was the sound of birds. We both spontaneously greeted him by kissing noses - a Sabunese custom for use whenever and wherever. He knew we were coming and told us to sit down. Uncle Robert had sent a telegram. Once inside I gave him a letter from Uncle Robert. I suspected it told him who I was and entrusted me to his care, as was the custom.

After chatting a while and listening to his advice, we were invited to breakfast. Never in my life had I had breakfast. Not because it was not common in Kupang, but because we didn't have enough food. I remember several times nearly passing out from hunger - once actually passing out - on the way home from primary school. But I tried the breakfast and got it down. It was the first time I ate tempe (fried soybean cakes).

Uncle Robert's letter had a history. The day after I told my mother that I wanted to go to Yogya, she went to visit two important officials. One was Uncle Robert, provincial head of the Education Department, the other Uncle Adi Boeky, East Nusa Tenggara deputy governor. I was astonished, because as far as I knew she had in all my 20 years only once before visited them, when I was still small. She told me they were relatives, but didn't communicate much. To me and to everyone in Kupang, they were 'big

${ }^{2}$ He actually died in 1962, some say of poisoning, but in any case just before the purges started late in 1965 (ed.). 
people'. Even more amazing was their reaction when they saw my mother; they greeted her warmly, called her 'susi Edo' and kissed her lightly nose to nose. This to Sabunese is the equivalent of shaking hands in Java, and at the same time a way of 'forgiving' each other. We children always did it on those rare occasions when Babu and Nene - our names for mum and dad - were angry. I don't know why, but once nose touched nose, the anger evaporated just like that.

As we sat in the guest room - in Uncle Adi Boeky as well as Uncle Robert's houses - mother introduced me in the Sabu language - or what Sabunese call Hawu, since they can't produce the letter 's'. She said: 'This is your child Ney' - this was my name in Kupang - 'Mone Miha', the eldest child. She confidently explained that I was 'going to school in Java' and asked for their advice. Uncle Adi immediately said, 'Yes, go to Yogya'. At first I was sure he would forget, but he didn't. When he came to Yogya two years later he asked me, via someone else, to meet him in the Garuda Hotel. Uncle Adi said lots of things, in the vein that I had to study hard, avoid bad friends and 'don't go with other people's kids'. Exactly what all old people tell their own kids. The conversation with Uncle Robert was even stricter. He didn't just support the Yogya plan, but he touched the small gold brooch my mother wore and said: 'If necessary Susi (the word for older sister that apparently comes from the Dutch), you have to sell this brooch.' He said lots more, then wrote a letter to Uncle Josef, whom he called Usu, even though in Yogya Uncle Josef was always known as Comrade (Bung) Jossie or Uncle Jossie, just as I am always known there as Connie.

To cut a long story short, I passed the test at last, and started my political science studies at UGM in 1980 . Seven years later I graduated and became a lecturer, until today.

\section{Dendeng}

I was born on 6 September 1959 in Dendeng, along a dead-end road south of the old town. My family still live there. I don't know when they came here, but dad once hinted it might have been 1948. Dendeng is actually the name of a small river, the only one in Kupang, which flows from the western side of town and has water even in the dry season. The Mapoli and Air Nona rivers flow into it from further south. But the name also refers to its small, sloping eastern bank, where our family lives along with a few others. People say the Dutch used to come to this cool place to swim. A lot of large banyan and cananga trees grow here, also right next to our 
house. There are fruit trees such as the tamarind, mangoes, lots of coconut and banana trees, breadfruit, guava and a few soursops.

Dendeng also supplies clean water. Right below our house the small tank the Dutch built still holds water. From here it flows through a pipe to the benteng, the Dutch fort at the river mouth that still serves as army barracks today. We thought of it as a military reservoir. Every year a group of soldiers came from the benteng to clean the inside of the tank, which was always covered. We never played on the tank when they were there. Sometimes they would come for an unannounced inspection, move off anybody illegally tapping water through a hole in the pipe they had made, and fix the holes.

The dam the Dutch also built here survived until the flood of early 1973. It had a little 'waterfall' in the middle, with a natural swimming pool below. This is where people swam, or learned to swim, and even held swimming races. They played 'water ball' with a plastic ball, or two people just splashed each other as hard as they could in the face using their hands in turn. In the end one would give up with stinging eyes. In the right corner of the pool there was a place with coloured clay - brown, red, white, yellow, blue and green - which we used to make dolls. A lot of fun. The clay also served as 'shampoo' and 'toothpaste' - we put some in our mouth and rubbed with the index finger. Crushed charcoal also made good toothpaste.

Electricity only reached Dendeng in 1982. In very small quantities, because it would go off every time someone used the electric iron. I never saw a telephone. Almost no one had electric lighting. Just the houses of the 'big people', the shops that were almost all owned by ethnic Chinese, and a few houses next to the power line, if they could afford it. By the way, having a house on the main road was not a question of socio-economic status. Lots of poor families lived along the main road, although some roads had mainly 'big people'.

My birthplace Dendeng lay only two or two and a half kilometres from the centre of town. It was a dark place, but not isolated. Two cars could pass on the road in. But not many people wished to live there. Only a few families were there until the 196os. There was Markus and his family, he was a communist who was condemned to death after Gestok. ${ }^{3}$ Their house had a stone wall, a zinc roof and a cement floor. It lay next to ours and until today his eldest daughter, Tante Net, still lives there with her

\footnotetext{
${ }^{3}$ Gestok = Gerakan Satu Oktober, the 1 October Movement, i.e. the failed communistmilitary putsch in Jakarta of 1 October 1965 that triggered bloody anti-communist purges in the months to follow.
} 
children and grandchildren. Her twin children, Adi and Kaka, were my playmates. Below that, near the river, was the Malada family home, the independence hero who gave his name to the road into Dendeng, Cak Malada Road. 'Cak' is a popular term of address equivalent to the 'bung' used by the Surabaya revolutionaries. In all of Kupang only two people were called Cak: Cak Malada and Cak Doko, the pioneer in education who was once education minister in the federal period of the late 1940s. The Malada family are highly educated. Their house is made of stone, with a zinc roof and a cement floor and surrounded by a large garden on the edge of the river. We called his daughter Tanta Malada. She once had a position in the Social Welfare Department, and died a spinster at the age of more than 8o. We had many other neighbours less famous than these.

With money my dad gave me I sometimes bought iced drinks from a middle-aged woman called Tante Kudji. She got the ice from the big factory called Minerva, owned by Koen Seong, a Chinese trader who was said to be the richest person in town. There were only two factories in town: the Minerva ice factory and a meat-processing factory called ICAFF, not far from the home of the raja of Kupang in the Mapoli area. I don't know who owned it, but it was said that Raja Nisnoni was one of them and that the others were foreign. It closed in the mid-1970s. Koen Seong's business went down because his children chose other professions and moved out of Kupang. His place as the town's richest was taken by the owner of Toko Piet, who built a five-storey shop, the biggest building in the heart of town. Toko Piet had the monopoly on the distribution of kerosene and petrol, perhaps until the present day.

Koen Seong's house stood on a sharp bend in the road just in front of the police station, close to the ' 40 Steps' and to the mouth of Cak Malada road, which led to Dendeng. It was a large house with a big garden, surrounded by a high fence topped with barbed wire. It was probably the only house in Kupang with such a high fence. Right behind it stood a huge mango tree. We often threw stones at it from Cak Malada road, trying to bring down the fruit. If any fell down, we climbed in through a gap between the wires on top of the wall. This was risky because, as the sign 'Beware of the Dog' said at the entrance, we often had to bolt to get away from the dog.

The '40 Steps' at the upper corner of Koen Seong's house was a stairway with that many steps. I always took a break there after selling my cakes and packets of rice. A number of shady tamarind trees stood there, a place for people to rest. We often went up and down these stairs counting the steps, but we could never agree on how many there were. Some counted 
40, others 41. The steps were a shortcut to the main road between Oeba and Kuanino, coming out just below the governor's residence - now the deputy governor's house. Next to the governor's house, and a little below it, stood Kupang's finest building, the Bank of Indonesia. It was built early in the 1970s on the old Chinese cemetery, which had been moved to who knows where. The opening ceremony was most impressive, as there were singers from Java. The ' 40 Steps' were one of many stairways in Kupang. I remember Kupang as a 'city of stairways'. All of them were shortcuts.

\section{Neighbours}

Life among the neighbours in Dendeng - as, I think, in Kupang generally was very happy. Of course there were enormous social differences. Sometimes this became a matter for gossip, particularly if someone from a wealthy family 'did not want to mix'. Other than that, interaction was intensive, familiar and egalitarian. When we went into the neighbour's house, we discovered that their rooms and kitchen were just normal. Women sitting down gossiping together while 'looking for lice' was a common sight. Of course, some people liked it more than others. Certain homes became 'gathering places'. In Dendeng that was Uncle Wielawa's house, followed by our own.

The most extraordinary economic difficulties never made people selfish. On the contrary, it merely increased the 'resource exchange' taking place among neighbours. My mother often sent me to the neighbours for salt, cooking oil, little chiles or some spices, because we had run out. And the neighbours gladly gave it. The reverse also happened. Sometimes they would just shout from the house or from the road, and we kids would take it over at a trot. That way everyone knew that family A was short of something and had asked the neighbours. But quite often any random kid that happened to be passing by would be asked to fetch it from the neighbour. Bringing food over was just as normal. It could be a piece of meat, fish, some vegetables or fruit, but also a slice of cake, some boiled maize or cassava, or anything else.

In Dendeng, in fact in any kampung, except where the government officials lived, it wasn't simply a matter of 'taking over some food'. Every family knew what their neighbours were eating every day. Asking what people were eating was normal. And everyone answered honestly, without hiding anything. If there was nothing besides rice they would say, 'we're out of food'. This answer would only stimulate the neighbour to offer their 
own vegetables (lauk) or immediately take some over to the neighbours. The question 'what are you cooking?' or 'have you cooked yet?' was heard every day in neighbours' chat. ${ }^{4}$ Whenever we children played at the neighbour's house - which was every day - their first question would be 'what are you eating at home? ${ }^{5}$ We would answer without hesitation. Often the neighbour would get us to take some food back before returning to play.

We all knew each other's clothes. If anyone left clothing behind at the river - after the wash, or drying on the rocks by the creek - we knew exactly whose it was, even underclothing. This was easy for us because everyone had few clothes. We even knew whose soap was left behind, or a bucket, or anything. Life in Dendeng, and probably in any Kupang kampung at that time, had no secrets, no privacy. But of course it was like the 'resource exchange', people had their own preferences: some kitchens we visited rarely, in some houses the neighbours rarely ate. Some neighbours' clothing everyone knew, others we had to ask first.

These relationships took no account of ethnicity or religion. The Chinese family just up the hill from our house - we called them 'Ence', a word like 'Baba' for Chinese generally - often exchanged resources with us and other neighbours. We kids spent a lot of time eating and playing at their house. The father was a Chinese migrant who we all believed was a Kuntao (Chinese martial arts) expert. He married a Sabu woman. He had a difficult life. His house was the same as ours and like most in the kampung - a grass roof and earthen floor. Their children -Johny, Big Mea and Dickson (who died in a motorcycle accident in year 2 of junior high) were my close mates. They sold food as I did. Likewise, my dad often received little gifts from 'Aci Kanaan', the owner of the Kanaan shop built in 1970 on the main road heading up to Kuanino, in front of the Sudimampir shop that had been there a long time. The Kanaan-Sudimampir area was a hangout for the (mainly Sabunese) kids from the Fontein neighbourhood, of which Dendeng was a part. Other families got such gifts, too. These intimate neighbourly relations were common in every kampung, except perhaps the elite neighbourhoods of government officials. When I first began regularly visiting an elite area like Tingkat I in the late 1970s, I didn't immediately notice the kind of intimacy we had in Dendeng. They had neighbourly relations involving various kinds of exchange, but it wasn't obvious on the surface.

\footnotetext{
4 'Masak apa? Su masak ko?'

5 'We bosong makan apa di rumah?'
} 
Until the 1970s, when Kupang people said they were relatives or family, they didn't mean something genealogical, but something social. Blood relations were of course an important foundation, but not the most important. Social relations were more decisive. Marriage relations, neighbours, mixing around and work were the points of reference for turning 'relative' into a social concept. The denser the relationship formed, the more strongly we would say they were relatives (saudara). All the neighbourly social relations in Dendeng - and in other kampungs, including the market (pasar) - were indicated by family terms: aunty, uncle, little sister, big sister, little brother, big brother (tanta, om, usi, kakak, a'a, bu). As far as I know, we only ever used the terms mister or sir, mistress or missus (bapak or pak, ibu or bu) for teachers and officials in the office. ${ }^{6}$ That wasn't even completely true for the latter, because unwittingly the more intimate expressions of uncle, aunty, brother or sister would bubble up in conversation in government offices, too. Occasionally we would use the word pak or $i b u$ to a neighbour, but only to tease them if they had just become an official. We would jokingly greet a big brother who had just become a civil servant by saying 'good afternoon, ooh mister civil servant'.

Being our elder or big brother or sister gave these social relations rights as well as obligations. They had the right to shout at us and often handed out punishment - a twist around the ears (kutitelinga), a slap (tempeleng) or tap (toki) and, most often, a tap or a whack with a twig (dipukul dengan ranting kecil) - and to boss us around, forbid things, et cetera. Not one of us minded, nor did any of our parents. Generally, after getting annoyed at us, they would tell another elder or older sibling, including our biological elders, and say, 'I just gave a tap to...', and the answer would always be the same: 'Ho.. that's OK...that'll teach him' - an expression of agreement and at the same time of thanks for doing the right thing and fulfilling social obligations to the young one. ${ }^{7}$ Sometimes we children would fall asleep at the neighbour's house. If that happened they would surely let us sleep, even till the next day. They would shout or send a message to our parents that we 'were sleeping next door', something that truly reflected the intimacy between neighbours. The neighbours' houses in Dendeng were my own house, and my house belonged to all the neighbours.

\footnotetext{
6 Although these terms also mean 'father' and 'mother', they are more formal and 'Indonesian' and so best translated as 'mister' and 'missus' (ed.).

7 'Beta baru toki si ......; Ho ...betul su... biar dia kapok.'
} 


\section{Things to Do}

That Dendeng was a quiet neighbourhood, even if that was not the whole picture, was true of Kupang in general. Of course there were exceptions, such as the shoot-out between military units around the time of Gestok. Shoot-outs between the police and the army were quite common in the mid-1970s. A really tense moment occurred just before dawn one morning in 1976. An armed unit of soldiers led by Jopy Makaraung - son of the Kupang Raya movie theatre guard - that had just come back from East Timor ${ }^{8}$ deliberately waited underneath Merdeka Bridge for a police unit that usually passed by there. Just as in war, they were lying on their bellies near the bridge that carried the main road, about 150 metres from Merdeka Field, the town's only football field and sports complex, and even closer to two technical high schools and the Catholic schooling complex. When a truck passed over the bridge the order to fire rang out. After several bursts they realized it was an air force truck carrying other soldiers. I never heard the end of it, but the whole city was tense and full of gossip. I have no idea why the enmity between police and army had run to weapons.

Dendeng itself also once nearly had a fatal incident. In the early 1970s a Buginese man ran around swinging a badik, a traditional Buginese sword, at people along the way. Several were wounded and, if I'm not mistaken, one person died. This almost led to an ethnic brawl. But once everyone understood the guy was crazy, the problem ended without revenge. The same thing happened with a Madurese saté seller in Kampung Baru in the late 1970s. And in the mid-1970s there was a rumour that a group from Alor armed with arrows - the traditional weapon in the island of Alor - were going to 'attack' or 'be attacked by' a group of Rotinese from a small neighbourhood called RRD (Republik Rakyat Dengka, the Dengka People's Republic) in the suburb of Kuanino. I'm not sure what the reason was. But as I heard it from Big Brother Kias Mauguru, an Alorese man who married my school friend Ande Leo's oldest sister Merie, it was triggered by a previous brawl in which one Alorese guy was seriously injured. I saw Alorese come and go across the Dendeng creek two or three nights in a row, because most Alorese live in Mantasi, the kampung across the creek from ours. But it all ended just with a rumour, without open conflict.

Massive brawls were rare in Kupang. Before the Alorese story I had never heard of anyone being mobbed like that. One-on-one fights happened

8 The Indonesian invasion of the Portuguese colony of East Timor in October 1975 led to years of warfare. Kupang was an important staging post for the war. 
more often, though even these could be counted on the fingers of one hand. It seemed to be a rule that the two sides wanting to duel would agree the location and time. Once it was over, regardless of who won, they would agree on the next time and place. Consequently these fights had lots of spectators, and no one intervened except to watch either passively or while actively encouraging one side. I remember clearly the 'serial duel' between two pairs of brothers, Brother Aba and Brother Dato (husband of my eldest sister) versus Brother Yunus Radja and Brother Minggus Radja. This duel took place repeatedly in the late 1960 s on the Dendeng creek dam. Each time it went on for a long time. Lots of people watched, many came specially to see it. The end of the story is that Brother Yunus Radja decided to leave for Surabaya to 'sign up for the army' (teken tentara) as a marine (KKO), while Brother Minggus Radja took off for Jakarta.

There were a few others like that, but the pattern was nearly always the same all over Kupang. Each one would be widely discussed. One that deviated from the pattern was a 'duel' between Ony Keang and 'Mister Moustache', a navy man. Ony Keang was a rascal, the mixed Chinese-Rote son of a tailor whose little brothers Elvis and Rickhy were my school mates. In this case a whole group of navy soldiers came looking for him afterwards and smashed up his house in Kampung Merdeka. He had to run away for a while. We heard from his little brothers that his father had been terrified.

At the market I had lots and lots of time. Dad was nearly always waiting for stuff, except when he was travelling into the interior. For me, after years of walking all over town from one end to the other with a clear purpose, selling things, this new atmosphere was extremely boring. That's when my friends and I tried to think of an alternative. At first we were happy just to stroll the lanes between the shops, looking for boards we might be able to use at home or to make games. But that got boring, too, after a while. At night we were busy around the Kupang Raya movie theatre. We 'sold stones' - a kind of white stone we found on the beach although with declining profits as the stones began to run out.

Gambling was another form of entertainment. I am not sure exactly when and who started to transform mete into a gambling affair. A few years earlier, in the late 196os, we children had often watched the adults play cards at the home of the deceased until dawn. This was called mete. At first it didn't involve money. People just played 'hang the ear' (gantong telinga), the same as we did in the market. But gradually games for money like '41' grew into the main reason to go and express one's condolences. I was clever at it, had a good instinct and some luck. My friend and 
neighbour, Ande Leo, financed my play, and joined in as well. We sometimes won big time, and bought lots of textile that Johny Hede sewed into clothes.

This doesn't mean, though, that there was no history of gambling. People say gambling had been part of market life practically for ever, even though I never saw or did it in the Pelita and the Oeba markets. According to mother, Sister Yaty and also people who had known father in the Kupang city market, gambling had been widespread. Father had been very much part of it. But in the 1950s and 1960s the players were restricted to a number of big papalele and Chinese entrepreneurs. They used to play more or less clandestinely at the market. The owner of Toko Timor, where we changed mother's large number of coins to help me on my way to Yogya, was one of my father's gambling mates from the past. Other social worlds had their forms of gambling: cock fighting and horse racing. I was involved in mete gambling for about a year. After that, I just returned to market life in 1976. I heard that the mete became more and more extreme, until they were doing roulette. Up until the time I left Kupang, at any house of mourning you would definitely see the gambling boss (bandar judi) setting up a game of roulette. Eventually the card games were abandoned and more and more people came to the mete places to play roulette.

The market where my parents had their stall for a time was right next to the navy headquarters, which occupied both sides of the road for hundreds of metres. On the seaside of the headquarters was a cemetery used by muslims from Kampung Solor. This cemetery was important to us, street kids from the market, especially after the late 196os, because at low tide it offered a shortcut into the navy complex via the reef. We could sneak in without being detected by the guard, notably by Mister Moustache, the navy man with a thick moustache and an athletic body whom we called go'eng. Every night films were projected on an outdoor screen. People had to buy a ticket, but here's the problem - we had no money. For those times when the tide was up and we couldn't get in via the sea, we had made a hole in the corrugated iron fence by bending the zinc sheet up in one corner. We always covered the hole with branches so they wouldn't see it. But it was a risky entrance, because the electric lights were bright and it was close to the main gate. We were often caught and then the punishment was - other than being shouted at; we were never beaten - to be locked in the toilets until the film was over. Sometimes those in charge forgot we were in the toilets and we would have to stay there all night. All the street and market kids had experienced it, at least once. 
The films varied a lot, and each one would be on for two or three weeks. Mandarin films were mainly martial arts. That's how we knew about David Chiang, Wang Yu, Ti Lung, and so on. One film we talked about for months was The magnificent seven..$^{9}$ Afterwards we would act out the film in fights among ourselves. Most enjoyable. Then there were the cowboy films, with names like Charles Bronson, Telly Savalas and Clint Eastwood, that we memorized. The most impressive was Clint Eastwood's For a few dollars more. We made pistols from kapok branches and imitated his way of shooting. Then there were the tear-jerker musical dramas, especially touching for us kids, such as the Dutch film - maybe it was Heintje - about a little singer with an extraordinary voice. ${ }^{10}$ Indonesian films came in two categories. Martial arts (silat) films like The blind man from Ghost Cave, Yellow bamboo and, especially, The skull poem ${ }^{11}$ familiarized us with stars like Ratno Timur and Dedy Sutomo. And love dramas in various settings, such as The Kedawung landlord, with its lovely star Suzanna, and a film like Tears of a stepchild, which made us cry with sadness. ${ }^{12}$ Quite often we would watch adult films like Breathing in the mud or Early marriage. ${ }^{13}$ It said 'For ages 17 and up', but no one ever cared if children were watching.

Bioskop Raya was a real movie theatre, a long and very old building next to the ice factory. The films here were newer than those in the navy complex. This was the only one in town, but it went broke after Bachtir built a luxurious new one in 1976. Bachtir was an ethnic Arab businessman, who owned a sawmill and a welding shop in Kampung Bonipoi next to the old mosque. He was the richest Arab in town. This one, too, went bankrupt after the first television came to town in 1977. TV radically changed the way we spent our evenings. Also, his tickets were too pricey for everyone except the few. Apparently the bankruptcy hit the whole Bachtir enterprise. A hotel he was building in Surabaya was abandoned and eventually sold to pay back the debts he had made to build his Kupang Theatre.

Mister Makaraung - I have no idea where he came from - we knew as the guard at the Bioskop Raya. He was already quite old, but still firm. In the front part of the theatre it narrowed a bit and there in a corner lived a crazy fellow we called Uncle Ako. He came from Rote and always wore the

\footnotetext{
9 A Mexican cowboy adventure (196o).

10 The German two-part series Heintje (1969 and 1970).

11 Si Buta dari Gua Hantu, Bambu kuning, Panji tengkorak.

12 Tuan tanah Kedawung, Ratapan anak tiri.

13 Bernafas dalam lumpur, Perkawinan dini.
} 
same full military uniform, military boots and red beret. Some people said he had not always been crazy, but because he had killed his Dutch superior officer, named Jongker, ${ }^{14}$ he pretended to be crazy to avoid justice. There were not many crazy people in Kupang. Besides Uncle Ako there was Crazy Wadu (Wadu Gila) from Sabu, who always walked around town naked and did 'yoga' every day. He always slept with his head down and his legs straight up in the air next to the bridge and the Pancasila monument near the mouth of the Dendeng creek, less than a hundred metres from the benteng. He could do this for hours, and would fall fast asleep in this position. Wadu Gila lived in the wreck of a wooden boat on the beach next to the pier.

Between 1969 and 1973, our market stall moved four times along the town's main road named Lahi Lahi Bisi Kopan. At first we stood at the threeways, on the corner of Ho Khian Hwat's shop, in the heart of town. After being evicted from there we moved a few dozen metres to the mouth of an alley leading to the home science junior high school where my sister Tina went, just next to Toko Baru. We stayed there a few months until we found a more strategic spot which, moreover, was more or less under cover and, even more important, had electric lighting. This was on the streetside corner of the old Toko Timor, which no longer functioned as a shop. It was about 30 metres from the previous place.

The front of Toko Timor was my favourite place. I often spent the night there. Actually, not many people slept on the street, except a few traders from the interior who had no house to go to. Most of my friends who played on the street and in the market went home at night. But I, Ony Sinlaeloe, Semi and, sometimes, one or two of my friends often slept on the ground in front of the shop. For me the reason was simple. When I returned from play I would sometimes find that father and the rest of the family had already gone home by themselves because the road home was unlit. Like most kids in Kupang, I was afraid of ghosts. Since we were little we were told stories of ghosts and along the road to my house there were many spots which they said 'had a ghost'. But this was just one third of the reason. Another third was that sleeping in front of the shop was closer to the beach where I could catch fish. Another reason was that I had to help my dad every morning to carry his gear from home to the market. Dad would almost without fail be off to the market at about 04:30 in order to beat other buyers to the best meat off-cuts (jeroan) that he resold.

\footnotetext{
14 Probably this is the honorific 'jongheer'.
} 
By sleeping here I didn't have to get up so early. At about 05:00 dad came by my place, which was only 200 metres from the Kampung Solor market. If I was still asleep, he would wake me up. But if my friends and I were at the beach, he would approach me only after he had completed his purchases. At night, it seemed as if the whole city was our own space, except for one or two corners among the shops where Timorese traders were snoring. There was no other sound besides our chatter: Kupang at night was a peaceful village, our village.

\section{Kites}

In July and August everyone flew kites. This is when the wind blew strong. Unlike in many other places, in Kupang flying a kite was not a matter of showing off its beauty, but to compete - we called it bahoro. The idea was to manoeuvre the line so it touched the rival's line. After that, we would let out the line in a certain way (we called it aria). The friction between the lines would - sometimes only after hours of this - eventually break one or the other's line, or sometimes both. We called it nao or anyo. It was very tense and many people came to watch from all over town. Bahoro required a special space, preferably rather high with few obstacles and a good strong constant wind. A cemetery on the top of a hill was among the favourite sites. In the kite season these places were full of young people. The most exciting part was to chase the kite that had been nao. We could race after it for 4 or $5 \mathrm{~km}$ and even - this was the nicest and happened the most often - we would swim way out to sea to fetch one, or climb a tree to get it down. Most of us carried a stick with a thorn on the end - called a ganco - to catch a kite before it hit the ground. In every season there were always one or two kites that never got nao. This was due to a good technique of letting out the line, and to a good quality of 'sharpening the line', which we called lolo galasan. Its owner was praised by the public.

There were many other games, also for the girls, and in all these variations my friends and I from the street and the market, like everyone else in Kupang, actively took part without caring about social class, ethnic background or religion. No game was closed to us. Not one part of the annual cycle left us behind, nor the kids from wealthy families. Even kids from the poorest families took part. Conversely, the wealth of children of 'big people' could never dictate a liking for different games to ours, nor did they create games exclusive to themselves. Class, ethnicity, religion and all that became irrelevant. Nor were the games just for kids - practically the whole 
town was involved. I could even say the whole city became one giant playground, with everyone participating. These meetings between different social circles created bonds of friendship and strengthened a collective identity. I feel that our identity and solidarity as Kupang people was to a great extent shaped here. Kupang in this period was nothing less than a gemeinschaft with a strong face, intensively interconnected through games and the language they created.

Most of the language we created during play, and which we later transferred to our daily conversation, was practically incomprehensible to our families. Father and mother didn't understand most of what we talked about. At home mother always spoke Sabunese. Father combined Indonesian, Kupang Malay and Sabunese. He was most exposed to Kupang Malay, because at the market that was the standard language, yet even he could only understand a bit of what we said. It took him a long time to understand and then begin to use some of it. This was the case in most families.

We didn't just produce words, we also disseminated them intensely through our cycles of play, even in quite dictatorial ways, to ensure they were widely used. It was always the same: we would insist on a word, regardless of whether other people understood it or not. Any kid who could not follow our pronunciation, or used one of our words at the wrong time, would be quickly expelled from our circle of play. We had several ways of doing this: laughing uproariously when anyone mispronounced a word was the most common. A more instinctive way was not inviting that person any more, or breaking up when the person concerned tried to become part of the game. In order to enter the circle of play everyone had to know the 'passwords'; this meant pronouncing words correctly and using them at the right moment. For older people we had another way. If anyone asked us what we were talking about, we would spontaneously answer: 'If you don't understand, go away!'15

\section{Big People}

In front of the Kupang market stood a neat row of shops selling household needs. In the corner to the north, separated by a narrow street, was an Indian shop selling 'cita cloth', mainly with flower motifs. On both sides of that shop, further north still, towards the beach, were two more shops,

15 'We bosong omong apa tu?'/ 'Kalo sonde mangarti pi jao-jao.' 
owned by ethnic Chinese; these shops didn't sell much, but functioned more as residences - the house with a shop. On the corner on the right was a photographer, a Chinese married to a Sabunese. In front of it was a streetside foodstall that closed down early in the 1970s. For about a kilometre towards the east, on both sides of the road, there were rows of Chinese shops, with just a few houses or businesses in between them, owned by indigenous people. Between 2 and 5 p.m. all the shops were closed. Their owners were 'taking a siesta' (tidor siang), while the shop attendants had gone home for lunch to do the same: tidor siang. The city was deserted during those hours.

Tidor siang was a very common practice. Probably it was due to the heat. Lots of adults, even in the market and the kampung, did it. It was practically universal among civil servants. Should a guest happen to come to the home of a civil servant, moreover a senior official, between the hours of 2 and 4 p.m. the normal answer would be 'father is taking his siesta.' ${ }^{16}$ Children were told to go out and play ${ }^{17}$ so as not to disturb the adults having their tidor siang. As for us children, tidor siang for the adults was the moment we had been waiting for, because it meant we could play without being disturbed by shouted orders from adults. We had usually taken off before we could be told to go.

Although I only ever went to church a few times, I knew it was full of worshippers every Sunday. Church and Sunday was not just for worship. It was a place and time to wear one's best clothes. Many families were very busy on Saturdays making clothes 'neat' (necis) - ironing them with the charcoal iron - for church. Church was the place where people first wore their new clothes. The main reason to buy new clothes was for church - a church shirt. Indeed the very first thing someone did who had just gotten a job with a salary, especially if they were a civil servant, was to 'buy a church shirt'. At Christmas time it was an absolute law for everyone. You went to the Christmas service in a new shirt - 'a Christmas shirt'. People knew when others wore a new shirt. 'Ooh a new shirt'18 is what friends, acquaintances or relatives said to each other at church. So church was at the same time a fashion show, a place where clothing sense was evaluated and shaped.

Important officials always sat in the front seats at church. Some helped out as 'elders', who arranged the Sunday service and circulated the black

\footnotetext{
16 'Bapa lai tidor siang.'

17 'Usir ana-ana dong pi barmain.'

18 'Baju baru oo!'
} 
collection bag. Everyone wore the very best and newest clothes they owned. Officials who made gifts sometimes did it anonymously, but more often by name. One of the elders read out the amount collected over the previous week, complete with names.

At primary school I had not a single book, not even an exercise book. I didn't even buy a pencil. Nor did I ever buy textbooks at junior or senior high school, but by then I did have some exercise books and pencils. After grade 2 the slate was no longer used, and pupils began to write in a book. I remember ours were always coloured blue, with whiteruled paper and a white square label on the front cover for the name. 'Leces' was the brand. We used a pencil to write. Ballpoints were unknown. Even in junior high few pupils used them. But I was not alone. Most of my Dendeng friends didn't have an exercise book either, except Abe. That's why my friends, Tinus Leo, Ande Leo and Darius Dimu, and I called by nearly every day at the rubbish heap outside 'Ikes', an office associated with the hospital less than a hundred metres south of our school, looking for waste paper. We scrabbled over anything we found. Fortunately there was always something there, even if it was mixed up with carbon paper. These were our 'books' at primary school. We never took them home. We had a 'safe storage place', in a convenient hole in the big ironwood tree about a hundred metres before our house. In the morning we came past there and retrieved our 'book' and pencil. I bought no books because I had no money.

This didn't mean I had no interest in reading. On the contrary, I loved it. If there was a book, I would read it. I remember living at Uncle Ney Dimu Djami a few months and reading the H.C. Anderson fairy tales that he had for his children Moni, Welly and Wati. But after that there were no books in my environment, and no one read. At home, my sister Yaty occasionally borrowed a novel from Sister Is Amos Pah. There were almost no newspapers. No one I knew subscribed to a newspaper. To the end of senior high school I had only occasionally read a newspaper, except when in year 3 we tried to find papers for a wall magazine we were making. Nor did I even read many school textbooks at primary or even junior high. The primary school had no library. Junior high had a small reading room with a little reading matter.

There's not much to say about junior high school. I certainly did not stand out academically. In three years I achieved nothing of note. Socially, too, I felt a bit isolated. I never visited school friends at home, or had them over to mine. I had friends to play with at school, but we didn't visit each other. Some of them I still remember: Kele Bala, Alo Koten, Fred Kaseh, 
Ako Nafie, Mat Kiwang, Yabes Kore, Paul Nggeok, Ney Hermanus, Alosius Dias Vera, Suk Dobleg, Alo Dembo, and some others who were quite close. But except for those who lived in the same Fontein neighbourhood as I Dickson and Johny Hede (the kids of 'Ence'), Lius Kore from around the cemetery, and a few others - they did not become playmates beyond school. My playmates were still the kids from the market and the street, and, of course, the neighbours. I felt junior high school was a time when I had little self-confidence, not sure why. Maybe because part of my soul was in another world, that of the market and the street. I still spent a lot of time in those places, and often still travelled into the interior as a papalele, skipping out on school. Nearly every week I missed some school, and every evening I was running around on the streets.

This was, I think, the period when I became aware of class differences. I realized I lived in a totally different world to that of my other friends who only seemed to know the world of school and play. This feeling of inferiority is a bit strange, because not one of my friends ever questioned anyone else's background, and being hard up was the rule for most people in this period. No other student ever remarked on my clothing or that of friends who were like me. Nor was there any discrimination in general conversation. Everything was as normal as anywhere else in Kupang. Maybe it was because they were no longer my familiar primary school playmates. Several of my primary school mates were now one year up on me, since I did not continue immediately after graduating then. Until now, I don't really know.

In 1976 I went back to the market, just as we moved from the Pelita to the Oeba market. Until my second semester of year 3 at senior high school I spent most of my time there. There wasn't a lot to do except to look after our goods. Occasionally I travelled into the interior, sometimes I worked casually on a building site to pour cement. I spent time with my highschool and kampung friends. But gradually hanging out by the side of the road or at the beach became rarer, and communicating with my street friends became more sporadic. We were each busy with our own little worlds. Even with my kampung friends I mixed less and less, except with one or two that I had known for a long time, even though the Pelita marketplace was right in the middle of a residential area. But Oeba was a new environment for me. My life became more routine. Reading, mainly nonschool books, became the new way of using my time. I especially read Ko Ping Ho martial arts stories. But I also liked borrowing books from the school library. The legendary Karl May serials left a big impression on me. I only learned after arriving in Yogya that Karl May never put a foot in the 
United States. Time for play also decreased drastically, although I still did it and I especially kept up my self-defence activities.

The junior-high-school principal was Mrs Karels, a highly respected disciplinarian from Rote. Most of our teachers were either Rotenese or Sabunese. There were Mr Fandu, Mr Pingak, Mr Adoe, Mr Piet and several others, all from Rote. But there was also Mr Gomang from Alor. And Mr Alex Rang, Mr Riwu and several others came from Sabu. Our Arab language teacher - we had Arab at junior high school - was Mrs Bamualim, who was of Arab descent. Among the students, on the other hand, the level of pluralism was very high. They came from practically every ethnic group in Indonesia, except Papua. Our school even had a student from Australia. I don't know what his parents did. Likewise, our senior high school had the whole range of social classes. Starting from the military commander's kids (two girls and a boy) - until about that time Kupang was the centre of some military region whose name and function I forgot through the children of the district head (bupati) Rol Adi and his younger sibling, down to kids from lower-class families such as mine.

Low interest in reading was the norm in Kupang at this time. Just a handful of people, usually senior officials, read the newspaper routinely and that was when the paper was nearly a week old. Even fewer people read books. Among students, very few read even school textbooks. Lack of interest eventually forced the Cempaka Wangi bookshop to move its business to Malang in Java in the late 1970s. My friend Dullah, when I met him in Yogya years later, as he was opening another bookshop there, told me he had to leave Kupang because no one was buying books. Most books on display were not touched for years. People would come in to borrow a Ko Ping Ho comic and that was it. Another little bookshop, called Merdeka as I recall and located near the benteng, went broke and closed down before that. But the amazing thing is that reading the Bible was apparently different. Many people read it all the time, and had even memorized parts of the Christian holy book.

George Eman, who accompanied me to Yogya, became a closer friend at this time. Both Ge's parents knew me well, and my parents knew that Ge belonged to the 'big people' (anak orang besar) who were prepared to be friends with 'little people' (orang kecil). These terms were very common social classifiers. 'Big people' was a general category for all bureaucrats (pejabat). I suspect it reflects the Sabunese custom of addressing officials as 'Mone Ae' - 'big person'. The term 'boss' was also used, or even repeated for emphasis as 'boss boss'. We often said 'he's a boss boss kid' (itu bos bos pung ana), sometimes adding the word 'big' so it became 'big boss'. It was 
used for officials and for anyone with money, including big Chinese traders. In the market, traders with strong capital were called 'big papalele' (papalele besar). The term 'businessman' (pengusaha) was hardly ever used. 'Rich person' (orang kaya) was only used when gossiping about a friend or neighbour who 'didn't want to mix'. Occasionally the phrase was 'now he's really become someone' (su jadi orang na), indicating social mobility for the whole family of someone who had become a civil servant. Lower-class people were generally called 'people with woes' (orang susah) or 'little people' (orang kecil). This was the general term for the lower classes, among families like our own and those of officials or businesspeople alike. Ge was called a 'big people's kid' because his father, a full-blood Dutchman, was a police lieutenant colonel, a former Dutch policeman who had decided to become an Indonesian citizen. As I recall he was one of the most senior policemen in Kupang, besides the Ully family.

Going in and out of the houses of friends whose parents were mainly officials like this gave me an opportunity to see how the 'big people' lived. There was little noticeable difference, except that my friends did not have to do any chores. They had a servant to do everything for them - cook, clean, wash dishes and clothes, and even make drinks. This was so different to the world I lived in every day, where we had to do everything ourselves. I also saw that their daily needs were never something to be discussed, unlike the houses of most lower-class people, where the problem of 'eating' was a daily topic of discussion. Children and parents always talked about the rice or the salt being finished. Parents in wealthy families routinely discussed 'appetite' instead: 'What do you feel like eating?'19 Whereas in most of our homes the commonest expression was: 'Hey go and borrow some rice from neighbour so-and-so!'20

I also noticed their lives were much neater and more hygienic. The water they drank had to be boiled first. They washed their hands before eating, and some even started the meal with prayer. That was something we never did at home, except at Christmas and New Year (kunci taon). Their lives were so organized that they had a fixed time for their meals; and the same for drinks. Whereas in our world eating time was set by how hungry the stomach was, and you might say drinking time had no place in our agenda at all. Whenever they ate they sat down at the table, at a plate with a spoon and fork neatly laid on either side. Every type of food had its own dish and even spoon. We never had such order in our

19 'Bosong mau makan apa?'

20 'We lu pi pinjam beras do di...' 
home. We usually just took our food straight out of the rice pot or out of the frying pan $(t a c u)$ whenever we felt hungry. We sat wherever as we ate. There was no dining table, no dining room. In short, the main difference between our world and that of the 'big people' was that for them eating was a cultural event, whereas for us it was simply a matter of survival, of filling the stomach.

\section{Conclusion}

During the funeral of my father in August 2006 I said: 'If I had to live my life over again and could choose, I would not hesitate to choose the same father, the same mother, the same family, the same city and the same life.' Beyond that, the long dialogue between the young Cornelis Lay and the old one - my method of self-interview - produced something new. I was astonished to discover that, in various ways, I was connected with almost every event and every place in Kupang. Whether this is the special character of a 'middle town' I don't know. But evidently every individual in a mid-sized town somehow becomes part of the complex yet paradoxically simple matrix of events taking place in that space. Almost no event happened of which I was not a part. There was no place in which I had not been. And I think all my friends in Kupang experienced the same thing. We were part of the process of creating and filling those spaces. 